\title{
PERUBAHAN SOSIAL MASYARAKAT NEGERI HENA LIMA PASCA BENCANA BANJIR WAE ELA DI KECAMATAN LEIHITU KABUPATEN MALUKU TENGAH
}

\author{
M.Syafin Soulisa \\ Jurusan Pengembangan Masyarakat Islam \\ Fakultas Ushuluddin dan Dakwah Institut Agama Islam Negeri Ambon \\ *) E-mail: finsoulisa@yahoo.com
}

\begin{abstract}
Intention of this research is to depict the condition of social change of society of Hena Lima pasca of disaster of floods of Wae Ela Yar 25 July 2013. Data collecting done by observation, interview and documentation. Research informan is society of victim of disaster of floods of Wae Ela Yar, elite figure, governmental of Hena Lima. this Research Result that first; the happening of social life change of society of pasca of disaster of floods Wae Ela marked with the change of at regional layout of resident housing, social relation of neighbour and consanquinity progressively go away the, change also at education systems, change of at social class status of society, individual attitude. [Both/ second]; Economic life change of society namely immeasurable progressively it society living among others as building labour, merchant, and other service work. Affect the change cause the society progressively individualism, estranged public relations progressively and more egoist having the character of and also feel depend on relief fund floods.
\end{abstract}

Keywords: Social Change, Hena Lima, Floods

\section{ABSTRAK}

Tujuan dari penelitian ini adalah untuk menggambarkan kondisi perubahan sosial masyarakat negeri hena lima pasca bencana banjir wae Ela 25 Juli 2013. Pengumpulan data dilakukan dengan cara observasi, wawancara dan dokumentasi. Informan penelitian adalah masyarakat korban bencana banjir Wae Ela, tokoh masyarakat, pemerintah Negeri Hena Lima. Hasil penelitian ini bahwa yang pertama; terjadinya perubahan kehidupan sosial masyarakat pasca bencana banjir Wae Ela yang ditandai dengan perubahan pada tataruang wilayah perumahan penduduk, hubungan sosial tetangga dan kekerabatan semakin menjauh, perubahan juga pada sistim pendidikan, perubahan pada status kelas sosial masyarakat, sikap individual. Kedua; perubahan kehidupan ekonomi masyarakat yakni semakin beragamnya mata pencaharian masyarakat diantaranya sebagai buruh bangunan, pedagang, dan pekerjaan jasa lainnya. Dampak perubahan menyebabkan masyarakat semakin individualisme, hubungan masyarakat semakin renggang dan lebih bersifat egois serta merasa tergantungan pada dana bantuan banjir.

Kata kunci: Perubahan Sosial, Negeri Hena Lima, Banjir

\section{PENDAHULUAN}

Masyarakat senantiasa mengalami perubahan di semua tingkat kompleksitas internalnya. Dalam kajian sosiologis, perubahan dilihat sebagai sesuatu yang dinamis dan tidak linear. Dengan kata lain, perubahan tidak terjadi secara linear. Perubahan sosial secara umum dapat diartikan sebagai suatu proses pergeseran atau berubahnya struktur atau tatanan didalam masyarakat, meliputi pola pikir yang lebih inovatif, sikap, serta kehidupan sosialnya untuk mendapatkan penghidupan yang lebih bermartabat, baik masyarakat tradisional maupun masyarakat modern, karena masyarakat pada dasarnya bersifat dinamis.
Perubahan terjadi dalam berbagai bidang kehidupan masyarakat, seperti bidang sosial, pendidikan, ekonomi, politik, ilmu pengetahuan dan teknologi, pertanian dan lain sebagainya. Perubahan sosial yang terjadi memberi efek bagi masyarakat secara menyeluruh, perubahan di satu bidang akan diikuti perubahan di bidang lainnya.

Pada tingkat makro, terjadi perubahan ekonomi, politik, sedangkan ditingkat mezo terjadi perubahan kelompok, komunitas, dan organisasi, dan ditingkat mikro sendiri terjadi perubahan interaksi, dan perilaku individual. Menurut Sztompka bahwa Masyarakat bukan sebuah kekuatan fisik (entity), tetapi 
seperangkat proses yang saling terkait bertingkat ganda. Masyarakat ada setiap saat dari masa lalu ke masa mendatang. Kehadirannya melalui fase antara apa yang telah terjadi dan apa yang akan terjadi. Dalam masyarakat kini terkandung pengaruh, bekas, dan jiplakan masa lalu serta bibit dan potensi untuk masa depan. Sifat berprosesnya sebab akibat secara tersirat berarti bahwa fase sebelumnya berhubungan sebab akibat sengan fase kini dan fase kini merupakan persyaratan sebab akibat yang menetukan fase berikutnya. ${ }^{1}$

Menurut Ali Amran bahwa efek yang ditimbulkan dari perubahan sosial masyarakat bisa berbe(ntuk positif dan juga bisa berbentuk negatif. Menurutnya, hal ini perlu ada benteng nilai dan norma yang bisa mengarahkan manusia dalam mengikuti perubahan sosial masyarakat yang terjadi dengan semakin pesat. ${ }^{2}$

Masyarakat Negeri Hena Lima pasca bencana banjir Wae Ela, dengan sendirinya memberikan dampak perubahan pada tingkatan kehidupan sosial mereka. Pada tingkat makro, akibat bencana banjir masyarakat Negeri Hena Limamengalami perubahan, misalnya pada sisi ekonomi dimana pendapatan dan pengahasilan masyarakat turun secara drastis dikarenakan hilanganya mata pencaharian baik di darat maupun di laut, banyak harta benda yang hanyut akibat banjir dan mereka harus memulai hidup yang baru.

Pada tingkat mezo terjadi perubahan pada kelompok masyarakat khususnya bagi mereka yang terkena langsung bencana banjir dan secara umum bagi masyarakat negeri Hena Lima, dimana mereka harus terlibat langsung untuk menampung saudara mereka yang terkena

${ }^{1}$ Sztompka, Piort, The Sociology of Social Change, dialihbahasakan oleh Alimudan dengan judul Sosiologi Perubahan Sosial, Jakarta: Prenada, 200. H. 65

${ }^{2}$ Ali Amran, Peranan Agama Dalam Perubahan Sosial Masyarakat, Jurnal HIKMAH, Vol. II, No. 01 Januari-Juni 2015. H. 23 bencana banjir Wae Ela. Pada tingkat mikro sendiri terjadi perubahan pada pola interaksi antara satu dengan yang lain, dimana korban banjir di tenda-tenda pengungsian harus berhadapan dengan model hidup yang sebelumnya belum pernah mereka alami, selanjutnya akibat bencana banjir juga berdampak pada perilaku individu masyarakat Negeri Hena Lima. Pada saat bencana tiba, secara psikologi pribadi mereka mengalami ganguan sehingga di butuhkan adanya pemulihan pasca bencana, namun dari pengamatan lapangan menurut sebagian masyarakat pemerintah maupun institusi lainnya belum menyediakan tempat-tempat pemulihan pasca bencana bagi pengungsi bencana banjir Wae Ela, sehingga berdampak pada karakter masyarakat khususnya pada anak dan remaja di Negeri Hena Lima.

Bencana sendiri sebagaimana di sebutkan adalah merupakan peristiwa atau rangkaian peristiwa yang mengancam dan mengganggu kehidupan dan penghidupan masyarakat yang disebabkan oleh faktor alam dan non-alam maupun faktor manusia sehingga mengakibatkan timbulnya korban jiwa manusia, kerusakan lingkungan, kerugian harta benda dan dampak lingkungan.

Sementara banjir merupakan suatu peristiwa alam biasa, kemudian berkembang menjadi suatu masalah bencana, jika air melimpahannya mengganggu kehidupan, penghidupan dan keselamatan manusia. ${ }^{3}$ Menurut Asdak bahwa risiko yang ditimbulkan bencana banjir tidak hanya memberikan dampak di daerah dimana kegiatan tersebut berlangsung, tetapi juga akan menimbulkan dampak di daerah hilir, seperti halnya penurunan kapasitas tampung waduk dan pendangkalan sungai dan

${ }^{3}$ Setyowati, Dewi Liesnoor, Erosi Dan Mitigasi Bencana. Semarang: CV. Sanggar Krida Aditama, 2010. H.76 
saluran-saluran irigasi yang pada gilirannya. Peristiwa banjir yang terjadi disebabkan oleh debit air sungai yang besarnya lebih dari biasanya akibat dapat meningkatkan risiko

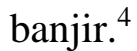

Indonesia sendiri merupakan salah satu negara yang banyak dilanda bencana. Dalam catatan Badan Nasional Penanggulangan Bencana (BNPB), Selama periode 2000 sampai 2011, dari sekian banyak bencana secara nasional, $77 \%$ bencana yang terjadi merupakan bencana hidrometeorologi, yaitu banjir, angin puting beliung, longsor. Pada bulan Januari 2013, terdapat sekitar 120 kejadian bencana di Indonesia. Akibat bencana tersebut maka 123 orang meninggal, 179.659 orang menderita dan mengungsi, 940 rumah rusak berat, 2.717 rumah rusak sedang, 10.798 rumah rusak ringan, kerusakan fasilitas umum lainnya. ${ }^{5}$

Selama periode tahun 1991 sampai 1995, misalnya, bencana banjir di Indonesia telah menimbulkan kerugian triliunan rupiah dengan korban jiwa sebanyak 4.246 meninggal, 6.635 luka-luka, dan sekitar 7 juta menderita serta 324.559 rumah mengalami kerusakan. Perkiraan kerugian tersebut belum memperhitungkan bencana banjir dalam skala kecil, kerugian immaterial dan kerugian tidak langsung yang tidak sedikit jumlahnya. ${ }^{6}$

Secara umum banjir yang terjadi di Negeri Hena Lima menimbulkan kerugian bagi masyarakat khususnya bagi mereka yang terkena banjir, baik secara langsung maupun tidak langsung. Kerugian akibat banjir Wae Ela yang dialami langsung oleh mereka yang rumah atau lingkungannya terkena air banjir, tidak

\footnotetext{
${ }^{4}$ Asdak, Chay, Hidrologi dan Pengelolaan Daerah Aliran Sungai. Yogyakarta: UGM Press. 2010. H. 12

${ }^{5}$ Badan Nasional Penanggulangan Bencana 2013: Bencana di Indonesia 2012.

${ }^{6}$ Badan Nasional Penanggulangan Bencana 2013: Bencana di Indonesia 2012.
}

hanya mencakup pada kerugian fisik material tetapi juga mencakup permasalahan sosial psikologis bagi mereka yang menjadi korban bencana.

Banjir Wae Ela adalah peristiwa jebolnya natural Dam Wae Ela di negeri Hena Lima, Kecamatan Leihitu Kabupaten Maluku Tengah-Maluku, pada tanggal 25 Juli 2013. Banjir Wae ela ini mengakibatkan 1.027 kepala keluarga (KK) atau 5.227 jiwa warga Negeri Lima mengungsi di tenda-tenda darurat yang dibuat seadanya di sekitar desa tersebut hingga ke desa tetangga. ${ }^{7}$ Bencana tersebut mengakibatkan 470 rumah rusak total, tiga buah bangunan gedung Sekolah Dasar (SD), satu buah bangunan Sekolah Menegah Atas (SMA), dua buah bangunan Mushalah, satu buah bangunan PUSKESMAS, satu buah bangunan Kantor koperasi Unit Desa (KUD), satu jembatan hanyut, sarana air bersih rusak total, dan satu menara seluler hanyut.

Olehnya masyarakat korban banjir dalam kondisi kekurangan dan keterbatasan kebutuhan sandang, pangan dan papan mereka ditempatkan di tenda-tenda pengungsi yang dibangun oleh Pemerintah Pusat, Provinsi Maluku, Badan Penanggulangan Bencana Daerah (BPBD) Maluku dan Lembaga sosial lainnya, dengan keterbatasan dan kekurangan makanan, pakaian, serta selimut. Dalam kondisi yang memperihatinkan Mereka juga diresahkan dengan ancaman terjangan air susulan karena pada saat itu hujan masih mengguyur Negeri Hena Lima. ${ }^{8}$ Banjir juga mengakibatkan ratusan

${ }^{7}$ http://regional.kompas.com/read/2013/07/26/14 08107/Wai.Ela.Jebol.Desa.Negeri.Lima.Jadi.Mirip.Lapan gan.Bola

${ }^{8}$ Syahbarwati, Insany, Disapu Air Wae Ela Sebagian Desa Negeri Lima Rata Dengan Tanah, Dalam; http://news.okezone.com/read/2013/07/26/340/842778/dis apu-air-wae-ela-sebagian-desa-negeri-lima-rata-dengantanah.http://elearning.gunadarma.ac.id/docmodul/pengant ar_sosiologi_dan_ilmu_sosial_dasar/bab7_perubahan_sos ial.pdf (diunduh pada 14 Mei 2016). 
tanaman cengkih, pala, kelapa dan tanaman lainnya hanyut, serta mempengaruhi aktivitas perekonomian di Negeri Hena Lima.

Perhatian pemerintah terhadap masyarakat Negeri Hena Lima pasca banjir yang belumlah maksimal, dengan sendirinya melahirkan beberapa masalah baru bagi masyarakat Negeri Hena Lima, diantaranya pemetaan pemukiman masyarakat yang tidak berdasarkan tata ruang wilayah sehingga penempatan kedudukan bangunan rumah tinggal warga sangat semraut. Tidak tersedianya lahan baru bagi masyarakat sehingga masyarakat menjadi sulit untuk menemukan lahan tempat tinggal, akibatnya lahan yang tadinya di tanami tanaman, harus ditebang dan di jadikan lahan tempat tinggal, secara ekonomis mereka harus kehilangan lahan hijau yang tadinya menjadi penunjang hidup keluarga.

Dari mekanis kerusakan banjir di atas, dampak akibat banjir yang melanda Negeri Hena Lima menyebabkan terjadi perubahan bagi kehidupan masyarakat. Olehnya peneliti tertarik mengkaji kondisi perubahan sosial yang terjadi pasca banjir Wae Ela di negeri Hena Lima, yang diharapkan dapat menganalisis dan menilai perubahan sosial kehidupan masyarakat pasca banjir yang terjadi di wilayah yang telah terkena bencana banjir Wae Ela dan telah banyak menyebabkan kerugian dalam segala aspek sosial masyarakat. Berdasarkan latar belakang diatas maka masalah dalam Tulisan ini adalah Bagaimana perubahan sosial masyarakat Negeri Hena Lima pasca Bencana Banjir Wae Ela?

\section{PENGERTIAN PERUBAHAN SOSIAL}

Pada dasarnya setiap masyarakat yang ada di muka bumi ini dalam hidupnya dapat dipastikan akan mengalami apa yang dinamakan dengan perubahan. Adanya perubahan tersebut akan dapat diketahui bila kita melakukan suatu perbandingan dengan menelaah suatu masyarakat pada masa tertentu yang kemudian kita bandingkan dengan keadaan masyarakat pada waktu yang lampau. Perubahan yang terjadi di dalam masyarakat, pada dasarnya merupakan suatu proses yang terus menerus, ini berarti bahwa setiap masyarakat kenyataannya akan mengalami perubahan-perubahan. Tetapi perubahan yang terjadi antara masyarakat yang satu dengan masyarakat yang lain tidak selalu sama. Hal ini di karenakan adanya suatu masyarakat yang mengalami perubahan yang lebih cepat bila dibandingkan dengan masyarakat lainnya.Perubahan tersebut dapat berupa perubahan yang tidak menonjol atau tidak menampakkan adanya suatu perubahan yang terjadi di masyarakat.Juga terdapat adanya perubahan yang memiliki pengaruh yang luas maupun yang terbatas.Disamping itu juga ada perubahan yang prosesnya lambat, dan ada juga perubahan yang prosesnya berlangsung dengan cepat.

Perubahan sosial merupakan gejala yang melekat di setiap masyarakat. Perubahanperubahan yang terjadi di dalam masyarakat akan menimbulkan ketidaksesuaian antara unsur-unsur sosial yang ada di dalam masyarakat, sehingga menghasilkan suatu pola kehidupan yang tidak sesuai fungsinya bagi masyarakat yang bersangkutan. ${ }^{9}$

William F. Ogburn mengemukakan bahwa runglingkup perubahan sosial mencakup unsure-unsur kebudayaan yang materiil maupun immaterial dengan menekankan bahwa pengaruh yang besar dari unsure-unsur immaterial. ${ }^{10}$ Kingsley Davis mengartikan perubahan sosial sebagai perubahan yang terjadi dalam fungsi dan struktur masyarakat.Perubahan sosial dikatakannya sebagai peerubahan dalam hubungan sosial

${ }^{9}$ Setiadi, Elly M., Ilmu Sosial dan Budaya Dasar, Jakarta: Prenada Media Group, 2006. H. 49

${ }^{10}$ Ibid. H. 51 
(social relationship) atau sebagai perubahan terhadap keseimbangan (equilibrium) hubungan sosial tersebut.

Menurut Selo Soemardjan, perubahan sosial adalah perubahan yang terjadi pada lembaga kemasyarakatan di dalam suatu masyarakat yang memengaruhi system sosial, termasuk di dalam nilai-nilai, sikap-sikap, dan pola prilaku di antara kelompok dalam masyarakat. Menurutnya, antara perubahan sosial dan perubahan kebudayaan memiliki satu aspek yang sama yaitu keduanya bersangkut paut dengan suatu penerimaan cara-cara baru atau suatu perbaikan cara masyarakat dalam memenuhi kebutuhannya. Perubahan sosial yaitu perubahan yang terjadi dalam masyarakat atau dalam hubungan interaksi, yang meliputi berbagai aspek kehidupan.Sebagia akibat adanya dinamika anggota masyarakat, dan yang telah didukung oleh sebagian besar anggota masyarakat, merupakan tuntutan kehidupan dalam mencari kestabilannya.

Kingsley Davis mengartikan perubahan sosial sebagai perubahan-perubahan yang terjadi dalam struktur dan fungsi masyarakat. MacIver membedakan antara utilitarian elements dengan culture elements yang didasarkan pada kepentingan-kepentingan manusia yang primer dan sekunder. ${ }^{11}$ Semua kegiatan dan ciptaan manusia dapat diklasifikasikan ke dalam kedua kategori tersebut. Artinya, semua mekanisme dan organisasi yang dibuat manusia dalam upaya menguasia kondisi kehidupannya, termasuk di dalamnya sistem-sistem organisasi sosial, teknik dan alat-alat material.

Gillin dan Gillin mendefinisikan perubahan sosial sebagai suatu variasi dari caracara hidup yang telah diterima, baik karena perubahan kondisi geografis, kebudayaan material, komposisi penduduk, ideologi maupun

${ }^{11}$ Soekanto, Soerjono, Sosiologi Suatu Pengantar, Jakarta: Raja Grafindo Persada, 1990. H. 301 karena adanya difusi ataupun penemuan baru dalam masyarakat. ${ }^{12}$ Menurut Talcott Parsons, masyarakat akan mengalami perkembangan menuju masyarakat transisional. Masyarakat akan berkembang melalui tiga tingkatan utama yaitu primitif, intermediate dan modern. Dari tiga tahapan ini, oleh Parsons dikembangkan lagi ke dalam subklasifikasi evolusi sosial sehingga menjadi 5 tingkatan yaitu; primitif, advanced primitif and arcchaic, historis internediate, seedbed sociaties dan modern sociaties. Parsons menyakini bahwa perkembangan masyarakat berkaitan erat dengan perkembangan keempat unsur subsistem utama yaitu kultural (pendidikan), kehakiman (integrasi), pemerintahan (pencapaian tujuan) dan ekonomi (adaptasi)

Menurut Blumer perubahan sosial merupakan sebuah usaha kolektif manusia untuk menegakkan terciptanya tata kehidupan baru. Ralp Tunner dan Lewis M. Killin mengkonsepsikan perubahan sosial sebagai kolektivitas yang bertindak terus-menerus guna meningkatkan perubahan dalam masyarakat atau kelompok.Perubahan sosial itu merujuk kepada perubahan suatu fenomena sosial di berbagai tingkat kehidupan manusia mulai dari tingkat individual hingga tingkat dunia. ${ }^{13}$

Menurut Salim perubahan sosial adalah suatu bentuk peradaban umat manusia akibat adanya pertambahan perubahan alam, biologis, fisik yang terjadi sepanjang kehidupan manusia. ${ }^{14}$ Perubahan sosial memiliki cakupan dari yang sederhana seperti dalam lingkungan keluarga hingga yang paling lengkap seperti tarikan kelembagaan dalam masyarakat.

${ }^{12}$ Narwoko, J. Dewi \& Bagong Suyanto, Sosiologi Teks Pengantar dan Terapan, Jakarta: Prenada Media, 2004. H. 350

${ }^{13}$ Ibid. H. 363

${ }^{14}$ Salim, Agus, Perubahan Sosial: Sketsa Teori dan Refleksi Metodologi Kasus Indonesia, Yogyakarta: Tiara Wacana Yogya, 2002. H. 1-2 
Perubahan sosial memiliki tiga kelompok teori yang bersifat melingkar (cyclic theory) yaitu: a) kelompok teori yang didominasi oleh perkembangan material dalam setiap pandangannya tentang realita, b) kelompok teori yang didominasi oleh pandangan non-material dalam setiap pandangannya tentang realita, c) kelompok teori yang didominasi perpaduan wawasan antara material dan non-material dalam setiap pandangannya tentang realita.

Perubahan sosial dapat dibedakan menjadi beberapa jenis sesuai dengan sudut pengamatannya.Misalnya dari sudut aspek, fragmen atau dimensi sistem sosial.Hal tersebut dikarenakan keadaan sistem sosial yang kompleks, tidak hanya berdimensi tunggal melainkan muncul sebagai kombinasi atau gabungan hasil keadaan berbagai komponen. Adakalanya perubahan sosial hanya terjadi sebagian kecil, terbatas ruang lingkupnya, tidak menimbulkan akibat yang besar terhadap unsur lain dari sesama sistem. Tidak terjadi perubahan yang menyeluruh atas unsur-unsurnya meski di dalamnya terjadi perubahan sedikit demi sedikit. $^{15}$

\section{GAMBARAN UMUM BANJIR WAE ELA}

Banjir Wae Ela adalah peristiwa jebolnya natural Dam Wae Ela di negeri Hena Lima, Kecamatan Leihitu Kabupaten Maluku Tengah-Maluku, pada tanggal 25 Juli 2013. Banjir Wae ela ini mengakibatkan 1.027 kepala keluarga (KK) atau 5.227 jiwa warga Negeri Lima mengungsi di tenda-tenda darurat yang dibuat seadanya di sekitar desa tersebut hingga ke desa tetangga. ${ }^{16}$ Bencana tersebut

\footnotetext{
${ }^{15}$ Sztompka, Piort, The Sociology of Social Change, dialihbahasakan oleh Alimudan dengan judul Sosiologi Perubahan Sosial, Jakarta: Prenada, 200. H. 3-4

${ }^{16}$ Patty, Rahman, Wai Ela Jebol, Desa Negeri Lima Jadi Mirip Lapangan Bola, Kompas.com, Kamis (25/7/2013)

dalam;http://regional.kompas.com/read/2013/07/26/14081
}

mengakibatkan 470 rumah rusak total, tiga buah bangunan gedung Sekolah Dasar (SD), satu buah bangunan Sekolah Menegah Atas (SMA), dua buah bangunan Mushalah, satu buah bangunan PUSKESMAS, satu buah bangunan Kantor koperasi Unit Desa (KUD), satu jembatan hanyut, sarana air bersih rusak total, dan satu menara seluler hanyut.

Olehnya masyarakat korban banjir dalam kondisi kekurangan dan keterbatasan kebutuhan sandang, pangan dan papan mereka ditempatkan di tenda-tenda pengungsi yang dibangun oleh Pemerintah Pusat, Provinsi Maluku, Badan Penanggulangan Bencana Daerah (BPBD) Maluku dan Lembaga sosial lainnya, dengan keterbatasan dan kekurangan makanan, pakaian, serta selimut. Dalam kondisi yang memperihatinkan Mereka juga diresahkan dengan ancaman terjangan air susulan karena pada saat itu hujan masih mengguyur Negeri Hena Lima. ${ }^{17}$ Banjir juga mengakibatkan ratusan tanaman cengkih, pala, kelapa dan tanaman lainnya hanyut, serta mempengaruhi aktivitas perekonomian di Negeri Hena Lima.

Peristiwa terjadinya banjir Wae Ela awal mulanya dari robohnya gunung Ulak Hatu sehingga menutup total daerah aliran sungai Wae Ela dan mengakibatkan air tidak bisa mengalir. Aliran sungai yang tersumbat material longsor Gunung Ulak Hatu (300 mdpl) itu membentuk danau dengan diameter sekitar 200 meter serta kedalaman diperkirakan mencapai hampir 100 meter.Longsor juga menutupi daratan berupa perkebunan yang ditanami ribuan pohon cengkeh dan pala.Ribuan warga

07/Wai.Ela.Jebol.Desa.Negeri.Lima.Jadi.Mirip.Lapangan. Bola

${ }^{17}$ Syahbarwati, Insany, Disapu Air Wae Ela Sebagian Desa Negeri Lima Rata Dengan Tanah, Dalam; http://news.okezone.com/read/2013/07/26/340/842778/dis apu-air-wae-ela-sebagian-desa-negeri-lima-rata-dengantanah.http://elearning.gunadarma.ac.id/docmodul/pengant ar_sosiologi_dan_ilmu_sosial_dasar/bab7_perubahan_sos ial.pdf (diunduh pada 14 Mei 2016). 
kesulitan mendapat air bersih untuk mandi dan mencuci.Untuk dapat bertahan, warga menggali lubang di bekas sungai untuk sekadar mendapat air. ${ }^{18}$

KONDISIPERUBAHAN

SOSIAL MASYARAKAT NEGERI HENA LIMA PASCA BANJIR WAE ELA

Masyarakat Negeri Hena Lima termasuk masyarakat petani karena sebagain besar yang menggantungkan hidupnya bekerja di bidang pertanian.Bencana banjir 25 Juli 2013 membawa perubahan bagi kehidupan masyarakat khususnya mereka yang tertimpa musibah banjir Wae Ela.Perubahan ini tidak hanya terlihat dari aspek fisik namun juga terlihat pada aspek non fisik seperti perubahan pada kehidupan sosial dan ekonomi.Suatu perubahan yang terjadi pada masyarakat negeri Hena Lima dapat diketahui dengan melakukan pengamatan terhadap keadaan sebelum dan sesudah bencana Banjir 25 Juli 2013.

Adapun bentuk perubahan kehidupan sosial masyarakat Negeri hena Lima pasca bencana banjir yang didapatkan oleh peneliti adalah terjadinya perubahan kehidupan sosial ekonomi masyarakat pasca bencana yang ditandai dengan semakin heterogennya kehidupan sosial seperti terbentuknya kelompok-kelompok baru dalam masyarakat berdasarkan hubungan kepentingan saja, terjadinya perubahan status sosial masyarakat.

Perubahan dalam kehidupan masyarakat negeri Hena Lima merupakan proses sosial yang di alami oleh anggota masyarakat dan sistemsistem sosial, di mana semua tingkat kehidupan masyarakat dipengaruhi oleh faktor eksternal seperti perubahan lingkungan fisik yang

\footnotetext{
${ }^{18}$ Wahyudi Mirahadi, Gunung Longsor $d i$ Maluku, Sungai Berubah Jadi Danau, dalam http://news.okezone.com/read/2012/07/15/340/663519/gu nung-longsor-di-maluku-sungai-berubah-jadi-danau
}

disebabkan bencana alam banjir 25 Juli 2013. Sehingga meninggalkan pola kehidupan dan sistem sosial yang lama kemudian menyesuaikan diri atau menggunakan pola-pola kehidupan sistem sosial yang baru agar tercapainya suatu keseimbangan pasca bencana banjir.

Penelitian ini menunjukan bahwa perubahan kondisi sosial masyarakat Negeri Hena Lima pasca banjir Wae Ela meliputi;

\section{Kondisi Perubahan sosial}

Kondisi sosial yang dimaksudkan adalah suatu keadaan atau perubahan yang terjadi pasca bencana banjir.Perubahan yang terjadi dalam suatu masyarakat atau suatu struktur sosial.Struktur sosial merupakan keseluruhan atau hubungan yang terdapat dan terkait dengan unsur unsur pokok sosial itu sendiri, yaitu lembaga sosial, kelompok sosial dan lapisan sosial khususnya disini lapisan sosial pada masyakat yang mengalami dampak banjir. Menurut Mistra dampak bencana banjir akan terjadi pada beberapa aspek dengan tingkat kerusakan berat salah satunya pada aspek sosial antara lain berupa korban jiwa/meninggal, hanyut, tenggelam, luka-luka, korban hilang, pengungsian, berjangkitnya wabah dan aktivitas jaringan kekerabatan terganggu. ${ }^{19}$

Kondisi sosial juga memengaruhi proses sosial dalam kehidupan masyarakat. Proses sosial merupakan proses interaksi antar komponen masyarakat dari waktu ke waktu hingga mewujudkan perubahan. Proses sosial yang terganggu karena perubahan sosial yang diakibatkan bencana itu sendiri berpengaruh pada berlangsungnya kegiatan sosial kehidupan bersama dalam masyarakat misalnya berpengaruh pada ekonomi terhadap politik, ekonomi terhadap agama dan sebagainya.

\footnotetext{
${ }^{19}$ Mistra, Antisipasi Rumah di Daerah Rawan Banjir, (Depok : Penebar Swadaya, 2007. H. 19
} 
Menurut Yudhistira, masalah sosial timbul dari kekurangan dalam diri manusia atau suatu kelompok sosial yang bersumber pada faktor berikut, 1) ekonomis, misalnya kemiskinan, pengangguran, dan bencana alam; 2) biologis, misalnya penyakit menular dan wabah; 3) psikologis, misalnya penyakit syaraf, bunuh diri, dan disorganisasi jiwa; 4) kebudayaan, misalnya kejahatan, perceraian, kenakalan remaja, konflik etnis dan konflik agama. ${ }^{20}$

Pasca banjir masyarakat dilarang untuk tinggal di daerah rawan bencana dan mereka mencari lokasi perumahan baru sehingga terjadi perubahan lingkungan fisik atau jarak sosial mengakibatkan lokasi perumahan mereka berjauhan.Bencana banjir Wae Ela berdampak pada perubahan tata ruang wilayah khususnya pada wilayah yang di jadikan pemukiman baru pasca bencana banjir. Menurut Ibrahim Maasily bahwa Kedudukan rumah penduduk tidak seperti dulu sebelum banjir, dimana letak rumah tertata bagus, namun pasca banjir penataan rumah penduduk tidak sesuai dengan tata ruang yang semestinya. Hal ini dikarenakan tidak ada perhatian pemerintah pasca banjir sehingga masyarakat yang terkena banjir membangun mengikuti kemaun sendiri, akibatnya ada rumah yang bagian depan berhadapan dengan bagian belakang rumah tetangga. Dapur bersebelahan dengan ruang tamu tetangga. Belum lagi di tambah dengan masalah pembuangan air limbah yang tidak pada tempatnya dikarenakan tidak tersedianya saluran pembuangan yang baik (Maasily, wawancara).

Akibat terjadinya jarak sosial masyarakat mengalami shock pada pemukiman baru,dimana mereka harus diperhadapkan dengan tetangga yang baru sehingga butuh adaptasi lingkungan yang dianggap cukup berat walau dalam satu daerah bencana. Kerinduan terhadap tetangga

${ }^{20}$ Yudhistira, Sosiologi Suatu Kajian Kehidupan Masyarakat. Jakarta : Ghalia Indonesia, 2006. H. 13 yang lama masih terasa. Menurut Said Heluth bahwa Kehidupan bertetangga yang dulunya penuh toleran, saling menghargai sekarang terputus karena akibat banjir. Disaat berada di pemukiman baru ada penyesuian yang sangat berat.Berat karena tetangga yang baru berbeda dengan tentangga yang sudah puluhan tahun hidup berdampingan walau dalam satu negeri. Dengan tetangga yang baru masih ada kekakuan dalam membangun relasi sosial keseharian (Said Heluth, wawancara).

Menurut Yusuf Heluth, mereka merasa Terharu ketika berjumpa dengan tentangga yang lama, ada semacam kerinduan yang dalam di antara kita, misalnya ketika berjumpa kemudian di ikuti dengan cerita-cerita sambil bertanya tentang kondisi masing-masing, hal tersebut terjadi dengan memkan waktu yang lama bisa 1 hingga 2 jam. Pokoknya ada kerinduan tersendiri dengan tetangga yang lama (FGD 30 Juli 2016).

Said mengatakan bahwa dia bersama tentangga yang baru ketika saling bercerita merasa ada perberbedan jika bercerita dan bercanda gurau dengan tetangga yang lama. Jika bersama tentangga yang lama mereka saling cerita apa adanya tanpa ada sekat karena kita merasa suda lama hidup berdampingan. Tapi jika dengan tetangga yang baru kita masih meras ada sekat walau sekarang suda hidup bertetangga, sehingga hal-hal yang lain yang tidak bisa kita ceritakan (FGD 30 Juli 2016).

Selain berjauhan dengan tentagga dan sanak saudara karena membentuk pemukiman baru, secara sosil budaya ikut mempengaruhi tatanan kehidupan pada masyarakat Soa, baik Soa yang terkena banjir (Hena Helu, Soa Ulisiahu dan Soa Elatua) maupun Soa yang tidak terkena banjir (soa Nau dan Hena lale). Pada sisi Sosial Budaya banjir wae ela juga mempengaruhi tatanan adat khususnya pada masyarakat soa mengalami perubahan. Secara struktur adat 
kepala soa ada, namun akibat banjir banyak warga masyarakat Soa sudah berada dan tinggal di Soa lain, Soa Ulisiahu sebagian besar masyarakatnya ada yang tinggal di Soa Nau dan Soa Hena Helu, Soa Elatu banyak yang tinggal di Soa Hena Helu, secara fisik keberadaan soa telah hilang namun kepala Soa dan warganya masih ada. ${ }^{21}$ Menurut Imran Soumena, musiba banjir Wae Ela ikut mempengaruhi tatanan adat khusunya anak soa (penduduk soa). Negeri hena lima sebagai negri adat yang terdiri dari lima soa dengan masing-masing di perintah oleh kepala soa, akibat banjir mereka harus terpisah dan telah tinggal dan menetap di soa yang lain. Namun menurutnya pemerintah Negeri Hena Lima akan berusaha membenahinya sehingga tidak hilang soa secara struktur pemerintahan adat. $^{22}$

Bencana banjir Wae Ela juga berdampak terhadap perubahan pada aktivitas proses pendidikan di Negeri Hena Lima, sesuai data bahwa banjir mengakibatkan tiga gedung Sekolah Dasar (SD), satu gedung Sekolah Menegah Atas (SMA) dan satu Taman KanakKanak (TK) hanyut terbawa banjir sehingga berdampak pada proses jalannya pendidikan di Negeri Hena Lima. Menurut Yusuf Heluth, bahwa akibat bencana banjir prestasi siswa di Negeri Hena Lima mengalami penurunan karena fasilitas pendidikan yang tidak memadai sehingga proses belajar mengajar berlansung di dalam tenda pengungsi yang di gunakan sebagai gedung sekolah. Fasilitas sarana dan prasarana pendidikan tidak sesuai standar untuk sebuah dunia pendidikan, misalnya fasilitas ruang kelas, kursi meja siswa, papan tulis dan kebutuhan lainnya. $^{23}$

Sarana prasarana sebagaimana yang di maksud dalam Peraturan Pemerintah Nomor 19

\footnotetext{
${ }^{21}$ Fuad Assel, FGD 30 Juli 2013

${ }^{22}$ Imran Soumena, Wawancara 01 Juli 2016

${ }^{23}$ Yusuf Heluth, FGD Juli 2016.
}

Tahun 2005 Pasal 42 adalah Pertama; Setiap satuan pendidikan wajib memiliki sarana yang meliputi perabot, peralatan pendidikan, media pendidikan, buku dan sumber belajar lainnya, bahan habis pakai, serta perlengkapan lain yang diperlukan untuk menunjang proses pembelajaran yang teratur dan berkelanjutan. Kedua; Setiap satuan pendidikan wajib memiliki prasarana yang meliputi lahan, ruang kelas, ruang pimpinan satuan pendidikan, ruang pendidik, ruang tata usaha, ruang perpustakaan, ruang laboratorium, ruang bengkel kerja,ruang unit produksi, ruang kantin, instalasi daya dan jasa,tempat berolahraga, tempat beribadah, tempat bermain, tempat berkreasi, dan ruang/tempat lain yang diperlukan untuk menunjang proses pembelajaran yang teratur dan berkelanjutan. ${ }^{24}$

Jika musim panas tiba \pm jam 10.30 kondisi suhu pada tenda ruang kelas sudah sangat panas sehingga mengakibatkan proses belajar mengajar tergangu dan harus belajar di luar tenda. Jika musim hujan tiba, ruang kelas tenda tergenang air dan becek.Memang sekarang pemerintah telah membangun tiga buah gedung sekolah Dasar namun sampai sekarang belum bisa di gunakan karena alasan teknis. ${ }^{25}$

Dilihat dari faktor masalah sosial, dalam aspek sosial terganggunya aktivitas pendidikan merupakan tragedi yang sangat memprihatinkan mengingat pendidikan mencerdaskan dan membudayakan kehidupan bangsa. Terganggunya aktivitas pendidikan akan membawa dampak perilaku masyarakat menjadi menurun karena ketidaktahuan makna dari pentingnya arti lingkungan. Sekaligus membawa dampak buruk pada psikologi

${ }^{24}$ Peraturan Pemerintah Republik Indonesia Nomor 19 Tahun 2005 Tentang Standar Nasional Pendidikan

${ }^{25}$ Yusuf Heluth, FGD 30 Juli 2016 
seorang jika mengalami dampak bencana yang serius.

Masyarakat negeri Hena Lima saat ini sangat menginginkan anak-anak mereka untuk bersekolah, mereka tidak ingin keadaan ekonomi pasca bencana banjir akhirnya membuat anak-anak mereka tidak dapat bersekolah.Jadi mereka tidak menginginkan anak-anaknya di kemudian hari putus sekolah yang disebabkan faktor finansial ekonomi keluarga. Apapun akan mereka lakukan demi melanjutkan pendidikan anak-anaknya, walau dengan cara pinjaman yang penting biaya pendidikan anak-anak mereka terpenuhi. Mereka berpandangan bahwa pendidikan dapat merobah status sosial mereka.

Terjadi juga perubahan dari status sosial masyarakat, dimana sebelum bencana banjir masyarakat yang berkedudukan tinggi dilihat dari kepemilikan modal usaha dan lahan sedangkan mereka yang berada di kelas bawah adalah mereka yang bekerja menjadi pekerja kasar. Namun pasca bencana banjir terlihat bahwasannya mereka yang memiliki modal, lahan dan buruh tani ini sama harus mencari sumber mata pencaharian baru karena dampak banjir membuat sebahagian besar lahan pertanian mereka rusak dan tidak dapat diolah lagi.

Kehidupan kita yang tertimpa musibah banjir hampir semua sama, terkecuali sebagian yang punya sedikit modal darai simpanan, secara umum kita sama-sama merasakan penderitaan akibat banjir, artinya tidak ada yang merasa lebih dan hebat, pembagian bantuan semua di samaratakan walau tadinya sebelum banjir memiliki kelebihan harta dari yang lain. Terkait perubahan status sosial ini, menurut Parsons (dikutip dalam Martono, 2011: 200) masyarakat memperkembangkan dua macam status yaitu: ascribed status yang mana lebih banyak berhubungan dengan kelahiran (turun temurun). Kedudukan tersebut didapatkan dalam masyarakat tanpa memperhatikan perbedaan-perbedaan kemampuan. Kemudian yang berikutnya adalah achieved status (status yang diperjuangkan) ini adalah kedudukan seseorang yang dicapai dengan usaha-usaha yang disengaja melalui perjuangan dan kerja keras. Status ini akan diperoleh individu sesuai dengan prestasinya dalam kehidupan masyarakat misalnya, tingkat jabatan tertentu yang dicapai melalui pendidikan, dan menjadi seorang pengusaha yang besar melalu kegigihan dan keuletanya.

Disisi lain, sebagai petani tentunya masyarakat sangat membutuhkan kehadiran orang lain. Pasca banjir mereka beralih pekerjaan masyarakat ke luar sektor pertanian sehingga mereka semakin sibuk dan berdampak pada kurangnya hubungan dengan sesama mereka. Sehingga untuk bertemu dan berkumpul dengan tetangga bahkan karib kerabat hanya pada waktu tertentu saja seperti pada saat perkawinan, ataupun pada tempattempat umum lainnya.

Kondisi masyarakat seperti ini menurut Bungin mengakibatkan masyarakat lebih bersikap invidualis dan perubahan pola pikir masyarakat dan sikap masyarakat terhadap berbagai persoalan sosial dan budaya, disekitarnya yang berakibat terhadap pola-pola pikir yang dianut oleh masyarakat. ${ }^{26} \mathrm{Hal}$ ini seperti berdampak pada sikap masyarakat pasca bencana banjir yang individualis yang di perlihatakan dengan tingkat kesibukan dengan pekerjaan masing-masing dan bersikap egois terutama dalam menerima bantuan dari pemerintah.

\section{Kondisi Perubahan Ekonomi}

${ }^{26}$ Burhan Bungin, Penelitian Kualitatif, Komunikasi, Ekonomi, Kebijakan, Publik, dan Ilmu Sosial Lainnya.Jakarta: Kencana, 2006, h. 91 
Manusia sebagai makhluk hidup mempunyai kebutuhan dan hubungan atau interaksi sosial maupun ekonomi, baik itu secara antar individu maupun kelompok dalam masyarakat. Masing- masing individu mempunyai kebutuhan berbeda beda dalam suatu masyarakat dan mepunyai upaya tersendiri pula dalam pemenuhannya. Untuk memenuhi kebutuhan dan keinginannya butuh proses dalam pembentukan lembaga dan kelompok sosial masyarakat. Dalam pemenuhan kebutuhan dan mengatur dibidang perekonomian dan melakukan kegiatan ekonomi biasanya didalam suatu kelompok sosial masyarakat terdapat suatu lembaga sosial yang mengaturnya. ${ }^{27}$

Kondisi ekonomi yang dimaksudkan adalah suatu keadaan dalam aspek ekonomi setelah bencana banjir Wae Ela, selain dampak dalam aspek sosial juga berpengaruh atau timbal balik ke dalam aspek ekonomi masyarakat yang terkena bencana banjir.Bencana banjir yang mengakibatkan kerugian dari aspek ekonomi di masyarakat berpengaruh dalam keberlangsungan kehidupan bersama. Dampak Bencana Banjir akan terjadi pada beberapa aspek dengan tingkat kerusakan berat salah satunya pada aspek ekonomi, antara lain berupa hilangnya mata pencaharian, tidak berfungsinya pasar tradisional, kerusakan, hilangnya harta benda, ternak dan terganggunya perekonomian masyarakat. ${ }^{28}$

Istilah ekonomi sendiri berasal dari kata Yunani yaitu "oikos"yang berarti keluarga atau rumah tangga dan "nomos" yaitu peraturan, aturan,hukum. Maka secara garis besar ekonomi diartikan sebagai aturan rumah tangga atau manajemen rumah tangga. Dalam Kamus Besar

${ }^{27}$ Supardi, Imam, Lingkungan Hidup dan Kelestariannya. Bandung: Alumni Bandung, 1994, h. 12

${ }^{28}$ Mistra, Antisipasi Rumah di Daerah Rawan Banjir, (Depok : Penebar Swadaya, 2007. H. 19
Bahasa Indonesia, ekonomi berarti ilmu yang mengenai asas-asas produksi, distribusi dan pemakaian barang-barang serta kekayaan seperti keuangan, perindustrian dan perdagangan. ${ }^{29}$

Menurut Damsar bahwa ekonomi merupakan kata serapan dari bahasa Inggris yaitu economy.Kata economy sendiri berasal dari bahasa Yunani yaitu oikonomike yang berarti pengelolaan rumah tangga.Yang dimaksud dengan ekonomi sebagai pengelolaan rumah tangga adalah usaha dalam pembuatan keputusan dan pelaksanaan yang berhubungan dengan penggunaan sumberdaya rumahtangga yang terbatas diantara berbagai anggotanya dengan mempertimbangkan kemampuan, usaha dan keinginan masing-masing.Maka dari itu, rumahtangga selalu dihadapkan pada banyak keputusan dan pelaksanaannya. Harus diputuskan anggota keluarga mana yang melakukan pekerjaan dan dengan imbalan apa serta bagaimana cara melaksanakannya. Dengan demikian, ekonomi merupakan suatu usaha dalam pembuatan keputusan dan pelaksanaannnya yang berhubungan dengan penggunaan sumberdaya masyarakat (rumahtangga/ perusahaan) yang terbatas diantara berbagai anggotanya dengan mempertimbangkan kemampuan, usaha, dan keinginan masing-masing. ${ }^{30}$

Negeri Hena Lima merupakan salah satu negeri yang berada di wilayah Kecamatan Leihitu Kabupaten Maluku Tengah.Dimana terjadi perubahan sosial dalam bidang ekonomi yang cukup signifikan pasca banjir Wae Ela.Masyarakat dengan mayoritas penduduknya bermata pencaharian sebagai petani dan hanya segelintir orang saja yang bermata pencaharian selain petani, seperti berdagang, buruh

${ }^{29}$ Depdikbud, Kamus Besar Bahasa Indonesia, Jakarta: Balai Pustaka, 1990, h. 251

${ }^{30}$ Damsar, Pengantar Sosiologi Ekonomi, Jakarta: Kencana, 2009, h. 9-11 
bangunan dan pegawai negeri sipil.Hidup mereka sangat bergantung kepada bidang pertanian Cengkeh, Pala, Kelapa dan tanaman lainnya.Memang hal tersebut didukung oleh lahan hutan yang sangat luas.

Sebelum banjir kondisi ekonomi warga masyarakat Negeri Hena Lima dapat dikatakan sangat bagus, namun sekarang mengalami perubahan yang sangat drastis karena sebagian besar warga kehilangan lahan perkebunanan tanaman produktif Cengkih, Pala dan Kelapa. Hilang bukan karena banjir semata akan tetapi hilang juga karena lahan di jadikan tempat tinggal. Bahkan ada yang mengalihkan dana yang tadinya di niatkan untuk ibadah haji, di ambil untuk kebutuhan pembangunan rumah, biaya sekolah anak, dan kebutuhan hidup keseharian.

Sejak tahun 2013 pasca bencana banjir Wae Ela hingga sekarang, banyak perubahan yang terjadi dalam bidang ekonomi di Negeri Hena Lima.Warga yang dulu mayoritas mata pencahariannya mengandalkan lahan petani sekarang sudah bertambah.Pasca bencana Banjir Wae Ela mereka melakukan perubahan pola mata pencaharian hidup keluar sektor pertanian. Adapun pekerjaan lain yang dilakukan masyarakat adalah sebagai buruh bangunan, pedagang, dan pekerjaan jasa lainnya. Dengan beragamnya pekerjaan masyarakat akan berpengaruh terhadap pendapatan, pola kosumsi dan gaya hidup masyarakat. Dengan demikian masyarakat sudah bisa menerima keadaan yang rawan dengan mampu untuk bertahan hidup dan keluar dari kondisi keterpurakan.

Banjir juga berpengaruh terhadap aktivitas usaha ekonomi mikro, kecil dan menegah di Negeri Hena Lima. Menurut Fuad Assel bahwa semenjak bencana banjir 2013 perekonomian masyarakat Negeri Hena Lima, utamanya yang bergerak di sektor usaha mikro dan usaha kecil sangat terpuruk, sementara tidak ada perhatian dari pemerintah. Misalnya tidak adanya pendataan terhadap kerugian dari usaha mereka, baik di tingkat pemerintah kabupaten maupun di tingkat negeri/desa ataupun kecamatan.

Perkembangan masyarakat Negeri Hena Lima dalam bidang ekonomi masi sangatlah memburuk.Sarana dan prasarana umum yang ada di Negeri Hena Lima belum tersedia sebagaimana mestinya.Begitu juga dengan rumah penduduknya, khususnya mereka yang tertimpa musibah banjir masih terdapat rumah yang tidak layak huni.Bantuan yang di berikan pemerintah belumlah mencukupi untuk membangun kembali rumah tempat tinggal dan kebutuhan hidup.

Memang kita telah mendapat bantuan dari BNPB sebesar 25 juta dan dinas sosial 15 juta, namun bantuan tidak sekaligus di terimah namun secara berangsur.dimana BNPB pada saat bencana banjir sehingga penggunaannya tidak teratur pada waktu yang sangat mendesak yakni harus membeli tanah, dan bantuannya datang di akhir Ramadhan sehingga korban bencana harus memenuhi kebutuhan ramadhan dan idul fitri dengan uang bantuan itu.

\section{PENUTUP}

Bencana banjir 25 Juli 2013 membawa perubahan sosial bagi kehidupan masyarakat Negeri Hena Lima khususnya mereka yang tertimpa musibah banjir Wae Ela. Perubahan ini tidak hanya terlihat dari aspek fisik namun juga terlihat pada aspek non fisik seperti perubahan pada kehidupan sosial dan ekonomi. Perubahan pada Kondis sosial yakni; pertama, bahwabencana banjir Wae Ela berdampak pada perubahan tata ruang wilayah khususnya pada wilayah yang di jadikan pemukiman baru pasca bencana banjir. Pasca banjir penataan rumah penduduk tidak sesuai dengan tata ruang yang semestinya.Hal ini dikarenakan tidak ada 
perhatian pemerintah pasca banjir sehingga masyarakat yang terkena banjir membangun mengikuti kemaun sendiri, Kedua; perubahan pada relasi sosial kekerabatan dan hidup bertetangga. Ketiga; terganggunya aktivitas proses pendidikan dan berdampak pada prestasi siswa karena fasilitas sarana dan prasarana pendidikan yang tidak memadai sebagaimana yang di amanahkan dalam Peraturan Pemerintah Nomor 19 Tahun 2005 Pasal 42. Keempat; perubahan pada status sosial masyarakat.Kelima; perubahan pada sikap masyarakat menjadi individualis dan egois yang diperlihatkan dengan tingkat kesibukan dengan pekerjaan masing-masing dan dalam menerima bantuan dari pemerintah.

Selanjutnya Perubahan pada Ekonomi masyarakat dimana semakin beragamnya mata pencaharian masyarakat, selain sebagai petani masyarakat juga bermatapencaharian sebagai buruh bangunan, pedagang penjual sayuran dan buah buahan, tukang ojek, menjual sembako dan pekerjaan jasa lainnya. Dengan beragamnya pekerjaan masyarakat akan berpengaruh terhadap pendapatan, pola kosumsi dan gaya hidup masyarakat

\section{DAFTAR PUSTAKA}

Asdak, Chay, Hidrologi dan Pengelolaan Daerah Aliran Sungai. Yogyakarta: UGM Press. 2010

Bungin, Burhan, Penelitian Kualitatif, Komunikasi, Ekonomi, Kebijakan, Publik, dan Ilmu Sosial Lainnya.Jakarta: Kencana, 2006

Badan Nasional Penanggulangan Bencana 2013: Bencana di Indonesia 2012.

Depdikbud, Kamus Besar Bahasa Indonesia, Jakarta: Balai Pustaka, 1990

Damsar, Pengantar Sosiologi Ekonomi, Jakarta: Kencana, 2009
Amran, Ali, Peranan Agama Dalam Perubahan Sosial Masyarakat, Jurnal HIKMAH, Vol. II, No. O1 Januari - Juni 2015

Mirahadi, Wahyudi, Gunung Longsor di Maluku, Sungai Berubah Jadi Danau, dalam http://news.okezone.com/read/2012/07/1 5/340/663519/gunung-longsor-dimaluku-sungai-berubah-jadi-danau

Martono, Nanang, Sosiologi Perubahan Sosial Prepektif Klasik, Modern, Posmodern, dan Perkolonial, Jakarta: PT Raja grafindo Persada, 2011

Mistra, Antisipasi Rumah di Daerah Rawan Banjir, (Depok : Penebar Swadaya, 2007

Narwoko, J. Dewi \& Bagong Suyanto, Sosiologi Teks Pengantar dan Terapan, Jakarta: Prenada Media, 2004

Patty, Rahman, Wai Ela Jebol, Desa Negeri Lima Jadi Mirip Lapangan Bola, Kompas.com, Kamis (25/7/2013) dalam;http://regional.kompas.com/read/2 013/07/26/1408107/Wai.Ela.Jebol.Desa. Negeri.Lima.Jadi.Mirip.Lapangan.Bola

Sztompka, Piort, The Sociology of Social Change, dialihbahasakan oleh Alimudan dengan judul Sosiologi Perubahan Sosial, Jakarta: Prenada, 200

Setyowati, Dewi Liesnoor, Erosi Dan Mitigasi Bencana. Semarang: CV. Sanggar Krida Aditama, 2010

Syahbarwati, Insany, Disapu Air Wae Ela Sebagian Desa Negeri Lima Rata Dengan Tanah, Dalam; http://news.okezone.com/read/2013/07/2 6/340/842778/disapu-air-wae-elasebagian-desa-negeri-lima-rata-dengantanah.http://elearning.gunadarma.ac.id/d ocmodul/pengantar_sosiologi_dan_ilmu _sosial_dasar/bab7_perubahan_sosial.pd f (diunduh pada 14 Mei 2016). 
Setiadi, Elly M., Ilmu Sosial dan Budaya Dasar, Jakarta: Prenada Media Group, 2006

Soekanto, Soerjono, Sosiologi Suatu Pengantar, Jakarta: Raja Grafindo Persada, 1990

Salim, Agus, Perubahan Sosial: Sketsa Teori dan Refleksi Metodologi Kasus Indonesia, Yogyakarta: Tiara Wacana Yogya, 2002

Yudhistira, Sosiologi Suatu Kajian Kehidupan Masyarakat. Jakarta : Ghalia Indonesia, 2006

Peraturan Pemerintah Republik Indonesia Nomor 19 Tahun 2005 Tentang Standar Nasional Pendidikan

abdulghofarismail.blgspot.com/kebijakan penanggulangan banjir, diakses pada 21 September 2014

Supardi, Imam, Lingkungan Hidup dan Kelestariannya. Bandung: Alumni Bandung, 1994 